\title{
Deteksi Ektoparasit pada Ikan Putak (Notopterus notopterus) di Provinsi Sumatera Selatan
}

\author{
Indah Anggraini Yusanti ${ }^{1 *}$, Sofian ${ }^{2}$, Rahma Mulyani ${ }^{3}$ \\ *E-mail : indahayusanti@gmail.com \\ ${ }^{1,2}$ Program Studi Ilmu Perikanan Fakultas Perikanan dan Kelautan \\ Universitas PGRI Palembang, Indonesia \\ ${ }^{3}$ Program Studi Budidaya Ikan Fakultas Perikanan dan Kelautan \\ Universitas PGRI Palembang, Indonesia
}

\begin{abstract}
Efforts in the management of pests of putak fish disease is the availability of information about ectoparasitic infections that attack putak fish so that ways or methods can be found to overcome it, it is necessary to conduct research aimed at identifying the type of ectoparasites, analyzing the prevalence index and rate of ectoparasites attacks in putak fish as preliminary data for efforts to manage and domesticate putak fish in South Sumatra. This study is an exploratory study, using purposive sampling method with 3 observation stations, namely station 1 putak fish shelter in Epil Village of Lais District musi Banyuasin, Station 2 putak fish shelter in Ogan Komering Ilir Regency and station 3 putak fish shelter in Sianjur 3 Palembang City. The results of the study obtained 2 types of ectoparasites namely Dactylogyrus sp and Trichodina sp found in the organs of fins, gills and mucus. The highest prevalence index was found at station 1, namely Dactylogyrus sp (gills $43.33 \%$, mucus 10\%), Trichodina sp (10\% gills, $10 \%$ mucus) and lowest at station 3 with no ectoparasites. The highest rate of ectoparasitic attack at station 1 is Dactylogyrus sp (gills 5.61 ind/tail, slime 8 ind/tail), Trichodina sp (gill 6 ind/tail, slime $11 \mathrm{ind} /$ tail).
\end{abstract}

Keywords : Ectoparasites, Putak Fish (Notopterus notopterus), South Sumatra Province,

\begin{abstract}
ABSTRAK
Upaya dalam pengelolaan hama penyakit ikan putak adalah ketersediaan informasi tentang infeksi ektoparasit yang menyerang ikan putak sehingga dapat ditemukan cara atau metode untuk mengatasinya, maka perlu dilakukan penelitian yang bertujuan untuk mengidentifikasi jenis ektoparasit, menganalisis indeks prevalensi dan tingkat serangan ektoparasit pada ikan putak sebagai data awal bagi upaya pengelelolaan dan domestikasi ikan putak di Sumatera Selatan. Penelitian ini merupakan penelitian eksploratif, menggunakan metode purposive sampling dengan 3 stasiun pengamatan, yaitu stasiun 1 penampungan ikan putak di Desa Epil Kecamatan Lais Kabupaten Musi Banyuasin, stasiun 2 penampungan ikan putak di Kabupaten Ogan Komering Ilir dan stasiun 3 penampungan ikan putak di Sianjur 3 Kota Palembang. Hasil penelitian diperoleh 2 jenis ektoparasit yaitu Dactylogyrus sp dan Trichodina sp yang ditemukan pada organ sirip, insang dan lendir. Indeks prevalensi tertinggi ditemukan pada stasiun 1 yaitu Dactylogyrus sp (insang 43,33\%, lendir 10\%), Trichodina sp (insang 10\%, lendir 10\%) dan terendah pada stasiun 3 dengan tidak ditemukan ektoparasit. Tingkat serangan ektoparasit tertinggi pada stasiun 1 yaitu Dactylogyrus sp (insang 5,61 ind/ekor, lendir 8 ind/ekor), Trichodina sp (insang 6 ind/ekor, lendir 11 ind/ekor).
\end{abstract}


Kata Kunci : Ektoparasit, Ikan Putak (Notopterus notopterus), Provinsi Sumatera Selatan

\section{PENDAHULUAN}

Keanekaragaman jenis ikan di perairan Indonesia tergolong tinggi. Sumatera Selatan dengan perairan umum daratannya yang luas, memiliki ikan-ikan yang khas. Salah satu komoditas perikanan yang bernilai ekonomis adalah ikan putak (Notopterus notopterus). Ikan putak memiliki rasa daging yang enak dan khas, sehingga ikan ini banyak diminati oleh masyarakat, khususnya masyarakat Sumatera Selatan untuk diolah menjadi berbagai macam makanan, yaitu pempek, tekwan, celimpungan dan makanan berbahan dasar ikan lainnya. Keberadaan ikan putak di perairan semakin langka, akibat dari penangkapan ikan putak yang berlebihan. Hal ini dapat berarti bahwa populasi ikan putak di alam akan semakin sedikit. Menurut Wibowo, dkk (2009), beberapa upaya yang dilakukan untuk meningkatkan populasi ikan Putak adalah melalui konservasi insitu, restocking, dan domestikasi.

Upaya budidaya ikan putak melalui kegiatan domestikasi ikan putak masih belum banyak dilakukan. Kendala utama dalam domestikasi ikan putak adalah sulitnya melakukan pemijahan ikan putak karena sampai dengan saat ini ikan putak masih tergolong ikan liar dan adanya hama penyakit yang menyerang ikan putak. Ektoparasit merupakan salah satu hama penyakit yang biasa ditemukan pada kegiatan domestikasi yang merupakan langkah awal untuk kegiatan budidaya ikan lokal. Menurut Agustinus dan Gusliany (2020), penyesuaian terhadap lingkungan budidaya menyebabkan tingkat stress yang tinggi pada ikan liar sehingga memudahkan ikan terserang penyakit. Infeksi ektoparasit dapat menjadi salah satu faktor predisposisi bagi infeksi organisme patogen yang lebih berbahaya seperi virus dan bakteri.

$\begin{array}{rrrr}\text { Salah } & \text { satu } & \text { upaya dalam } \\ \text { pengelolaan } & \text { ikan } & \text { putak untuk }\end{array}$ mendukung keberhasilan budidaya ikan putak adalah ketersediaan informasi tentang infeksi ektoparasit yang menyerang ikan putak sehingga dapat ditemukan cara atau metode untuk mengatasinya. Berdasarkan hal tersebut, maka perlu dilakukan penelitian untuk mengidentifikasi jenis ektoparasit, menganalisis indeks prevalensi dan tingkat serangan ektoparasit pada ikan putak sebagai data awal bagi upaya pengelelolaan dan domestikasi ikan putak di Sumatera Selatan.

\section{MATERIAL DAN METODE}

\section{Subjek Penelitian}

Penelitian ini akan dilakukan pada bulan Juli hingga Agustus 2021 bertempat di Kabupaten Musi Banyuasin, Ogan Komering Ilir dan Palembang. Identifikasi ektoparasit dilakukan di Workshop Pembenihan Ikan Fakultas Perikanan dan Kelautan Universitas PGRI Palembang.

Alat dan Bahan yang digunakan

Alat yang digunakan pada penelitian ini meliputi stereofoem, plastic, mikroskop, pisau, timbangan analitik, pipet tetes, jangka sorong, kamera digital dan alat tulis. Sedangkan bahan yang digunakan dalam penelitian ini yaitu ikan putak, $\mathrm{NaCl}$, akuades.

\section{Metode Penelitian \\ Penelitian ini menggunakan metode purposive sampling dengan 3 stasiun pengamatan yaitu stasiun 1 penampungan ikan putak di Desa Epil}


Kabupaten Musi Banyuasin, stasiun 2 penampungan ikan putak di Desa Sri Geni Kabupaten Ogan Komering Ilir, dan stasiun 3 penampungan ikan putak di Sianjur 3 Kota Palembang. Ikan hasil tangkapan dipisahkan berdasarkan stasiun dan diberi label, kemudian dimasukan ke dalam stereofoem untuk proses transfortasi ke WSPI Fakultas Perikanan dan Kelautan. Kemudian ikan diukur dan dianalis.

\section{Data Pengamatan}

a. Identifikasi Ektoparasit. Identifikasi ektoparasit ikan putak dilakukan dengan cara pengambilan sampel pada sirip, insang, dan lendir. Kemudian sampel di identifikasi menggunakan mikroskop. Penentuan jenis ektoparasit yang ditemukan mengacu pada buku Kabata (1985).

b. Indeks Prevalensi

Perhitungan indeks prevalensi ektoparasit ikan putak mengacu pada Bayumi (2021), yaitu :

$$
\mathrm{P}=\Sigma \frac{N}{n} \times 100 \%
$$

Keterangan :

$\mathrm{P}=$ Prevalensi (\%)
$\mathrm{N}=$ Jumlah ikan yang terinfeksi parasit (ekor)

$\mathrm{n}=$ Jumlah sampel yang diamati (ekor)

c. Intensitas serangan ektoparasit

$$
\text { Perhitungan intensitas }
$$
serangan ektoparasit ikan putak mengacu pada Yuli (2017), yaitu

$$
\mathrm{I}=\sum \frac{P}{n}
$$

Keterangan :

$\mathrm{I}=$ Intensitas serangan parasit (ind/ekor)

$\mathrm{P}=$ Jumlah parasit yang menyerang (ind)

$\mathrm{n}=$ jumlah ikan yang terinfeksi

parasit (ekor)

\section{Analisis Data}

Analisis data dilakukan secara deskripsi dengan membandingkan data hasil penelitian dengan standar yang ada dan disajikan dalam bentuk table dan gambar.

\section{HASIL DAN PEMBAHASAN}

Hasil identifikasi ektoparasit pada ikan putak (Notopterus notopterus) asal Kabupaten Musi Banyuasin, Ogan Komering Ilir dan Kota Palembang selengkapnya disajikan pada Tabel 1 berikut ini.

Tabel 1. Hasil Identifikasi Ektoparasit pada Ikan Putak Asal Kabupaten Musi Banyuasin, Ogan Komering Ilir dan Kota Palembang.

\begin{tabular}{|c|l|c|c|}
\hline No & \multicolumn{2}{|c|}{ Uraian } & \multicolumn{2}{c|}{ Spesies Parasit } \\
\cline { 3 - 4 } & & Dactylogyrus sp & Trichodina sp \\
\hline 1 & Filum & Platyhelminthes & Protozoa \\
2 & Kelas & Trematoda & Ciliata \\
3 & Genus & Dactylogirus & Trichodina \\
4 & Spesies & Dactylogyrus sp & Trichodina sp \\
5 & Organ Yang Terinfeksi & & \\
& - Sirip & + & + \\
& - Insang & + & + \\
& - Lendir & + & + \\
\hline
\end{tabular}


Dari Tabel 1 diatas, terdapat 2 jenis ektoparasit yang ditemukan, yaitu Dactylogyrus sp dan Trichodina sp.

1. Dactylogyrus $\mathrm{sp}$

Dactylogyrus sp merupakan golongan parasite kelas Trematoda / Monogenea yang dikenal dengan nama Gill Fluke. Dactylogyrus sp berkembang biak dengan bertelur, berbentuk pipih dorsoventral, simetris bilateral dan memiliki 2 pasang jangkar. Menurut
Yusuf, et al (2020), Dactylogyrus sp memiliki alat penghisap bercabang 4 yang berfungsi untuk menempel dan bergerak pada permukaan tubuh inangnya. Berdasarkan hasil pengamatan, ektoparasit Dactylogyrus sp ditemukan di sirip, insang dan lendir pada ikan putak.

Gambar Dactylogyrus sp pada penelitian ini disajikan pada Gambar 1 berikut ini.

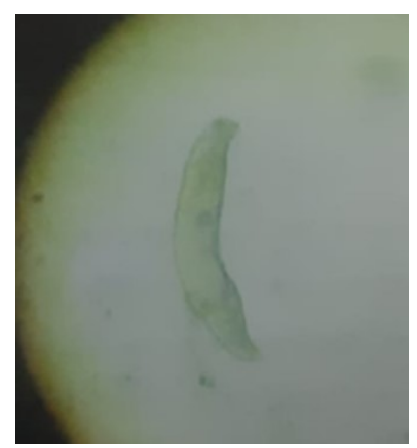

Gambar 1. Parasit Dactylogyrus sp

(Sumber : Dokumentasi Pribadi, 2021)

\section{Trichodina $\mathrm{sp}$}

Trichodina sp. adalah parasit protozoa bercilia yang menyerang benih maupun ikan budidaya air tawar. Ektoparasit Trichodina mempunyai peranan pada penurunan fisiologis tubuh, penurunan daya kebal tubuh dan sebagai predisposisi terjadinya infeksi sekunder. Parasit ini Parasit ini berkembang biak dengan cara pembelahan yang berlangsung pada tubuh inang, mudah berenang secara bebas, dapat melepaskan diri dari inang dan mampu hidup lebih dari dua hari tanpa inang. (Utami, 2016). Berdasarkan hasil pengamatan, ektoparasit Trichodina sp ditemukan di sirip, insang dan lendir pada ikan putak.

Gambar Trichodina sp pada penelitian ini disajikan pada Gambar 2 berikut ini.

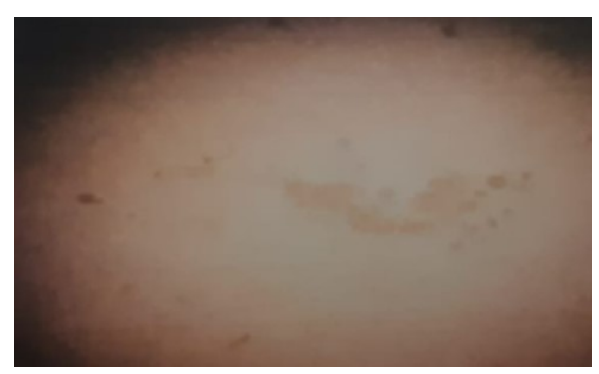

Gambar 2. Parasit Trichodina sp

(Sumber : Dokumentasi Pribadi, 2021) 
Ektoparasit Dactylogyrus sp dan Trichodina sp menyerang pada organ sirip, insang dan lendir. Organ insang yang terkena ektoparasit mengalami pengeluaran lendir yang banyak, sehingga insang mengalami iritasi dan mengering. Jika terdapat dalam jumlah yang banyak pada ikan dapat menyebabkan kematian pada ikan.

Pengukuran indeks prevalensi ektoparasit pada ikan putak (Notopterus notopterus) disajikan pada Tabel 2 berikut ini.

Tabel 2. Nilai Rata-rata Indeks Prevalensi Ektoparasit Ikan Putak Asal Kabupaten Musi Banyuasin, Ogan Komering Ilir dan Kota Palembang.

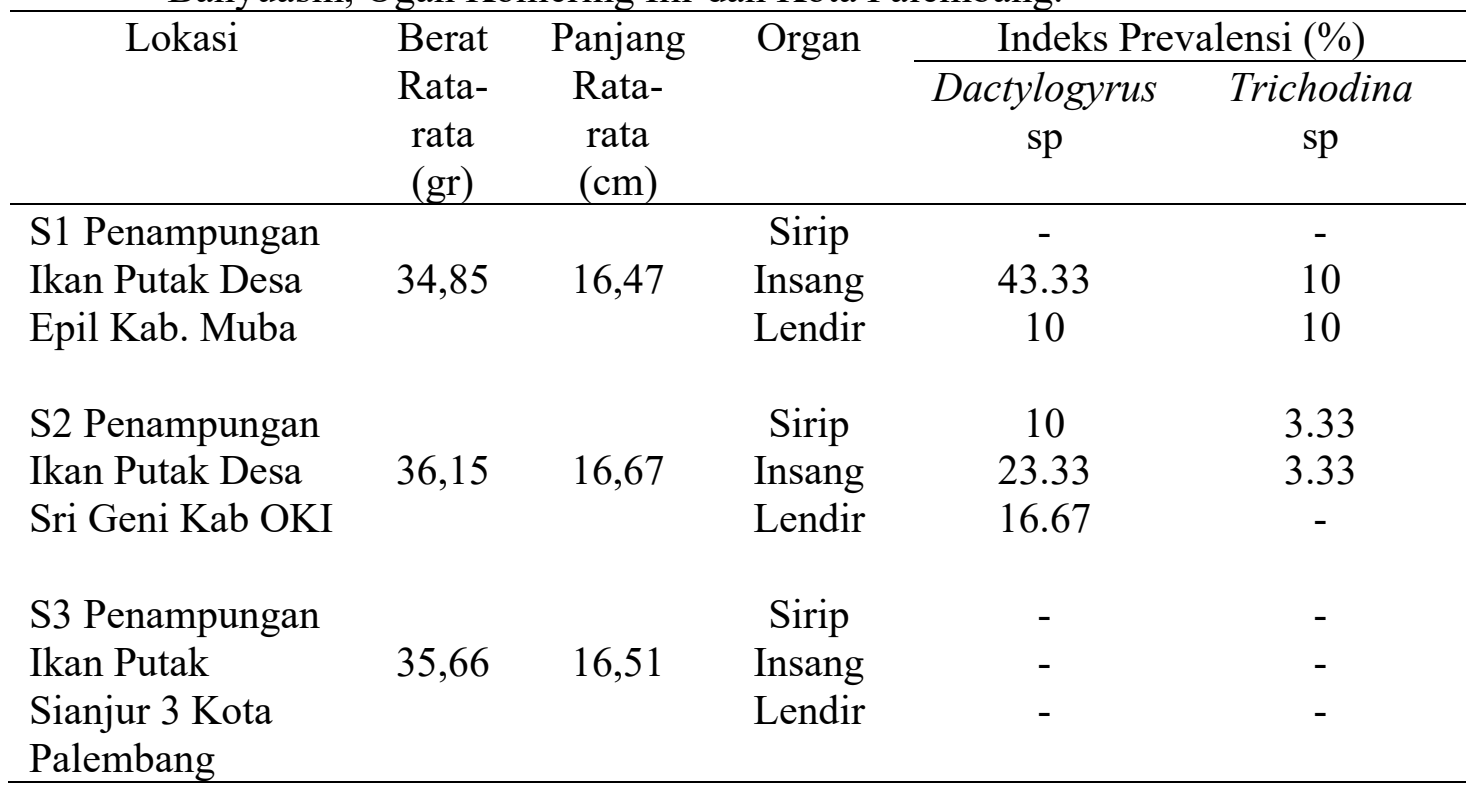

Berdasarkan Tabel 2 di atas, diketahui bahwa indeks prevalensi Dactylogyrus sp pada ikan putak (Notopterus notopterus) asal Kabupaten Musi Banyuasin, Ogan Komering Ilir dan Kota Palembang pada stasiun 1 sebesar $43,33 \%$ pada bagian insang dan $10 \%$ pada bagian lendir, stasiun 2 sebesar $10 \%$ pada bagian sirip, 23,33\% pada bagian insang, $16,67 \%$ pada bagian lendir dan stasiun 3 tidak ditemukan adanya ektoparasit pada ikan putak. Sedangkan indeks prevalensi Trichodina sp pada ikan putak (Notopterus notopterus) asal Kabupaten Musi Banyuasin, Ogan Komering Ilir dan Kota Palembang pada stasiun 1 adalah sebesar $10 \%$ pada bagian insang dan lendir, stasiun 2 sebesar $3,33 \%$ pada bagian sirip dan insang. Untuk stasiun 3 tidak ditemukan adanya ektoparasit pada ikan putak.

Menurut William dan Bunkley (1996) dalam Yuli et al (2017), kriteria indeks prevalensi infeksi ektoparasit disajikan pada Tabel 3 berikut ini. 
Deteksi Ektoparasit pada...,...Indah A.Y., Sofian dan Rahma M., ...Sainmatika, ...Volume 18, ...No.2, ... Desember $2021, \ldots 199-207$

Tabel 3. Kriteria Indeks Prevalensi Infeksi Ektoparasit Menurut William dan Bunkley (1996) dalam Yuli et al (2017).

\begin{tabular}{cllc}
\hline No & Tingkat Serangan & \multicolumn{1}{c}{ Keterangan } & Indeks Prevalensi (\%) \\
\hline 1 & Selalu & Infeksi Sangat Parah & $100-99$ \\
2 & Hampir Selalu & Infeksi Parah & $98-90$ \\
3 & Biasanya & Infeksi Sedang & $89-70$ \\
4 & Sangat Sering & Infeksi Sangat Sering & $69-50$ \\
5 & Umumnya & Infeksi Biasa & $49-30$ \\
6 & Sering & Infeksi Sering & $29-10$ \\
7 & Kadang & Infeksi Kadang & $9-1$ \\
8 & Jarang & Infeksi Jarang & $>1-0,1$ \\
9 & Sangat Jarang & Infeksi Sangat Jarang & $>0,1-0,01$ \\
10 & Hampir Tidak Pernah & Infeksi Tidak Pernah & $>0,01$ \\
\hline
\end{tabular}

Nilai indeks prevalensi ektoparasit Dactylogyrus sp yang ditemukan pada stasiun 1 dengan nilai prevalensi sebesar $10 \%$ pada bagian lendir berada pada kriteria infeksi sering yang mengindikasikan bahwa level tingkat serangan ektoparasit Dactylogyrus sp termasuk sering menginfeksi ikan putak, nilai prevalensi sebesar $43,33 \%$ pada bagian insang berada pada kriteria infeksi biasa yang mengindikasikan bahwa level tingkat serangan Dactylogyrus sp termasuk pada umumnya menginfeksi ikan putak. Untuk stasiun 2, nilai prevalensi sebesar $10 \%$ pada bagian sirip termasuk kriteria infeksi sering yang mengindikasikan bahwa level tingkat serangan ektoparasit Dactylogyrus sp termasuk sering menginfeksi ikan putak. Nilai prevalensi sebesar $23,33 \%$ pada insang termasuk dalam kriteria infeksi sering yang mengindikasikan bahwa level tingkat serangan ektoparasit Dactylogyrus sp termasuk sering menginfeksi ikan putak dan nilai prevalensi sebesar $16,67 \%$ pada bagian lendir termasuk dalam kategori infeksi sering yang mengindikasikan bahwa level tingkat serangan ektoparasit Dactylogyrus sp termasuk sering menginfeksi ikan putak. Pada stasiun 3 tidak ditemukan ektoparasit.
Nilai prevalensi ektoparasit Trichodina sp yang ditemukan pada stasiun 1 dengan nilai prevalensi sebesar $10 \%$ pada bagian insang dan lendir termasuk kriteria infeksi sering yang mengindikasikan bahwa level tingkat serangan ektoparasit Trichodina sp termasuk sering menginfeksi ikan putak. Pada stasiun 2, nilai prevalensi sebesar $3,33 \%$ pada bagian sirip dan insang termasuk kriteria infeksi kadang yang mengindikasikan bahwa level tingkat serangan ektoparasit Trichodina sp termasuk kadang-kadang menginfeksi ikan putak. Pada stasiun 3 tidak ditemukan ektoparasit.

Level tingkat serangan ektoparasit Dactylogyrus sp dan Trichodina sp yang termasuk sering menginfeksi ikan putak diduga disebabkan karena kedua jenis ektoparasit ini termasuk ektoparasit yang mudah beradaptasi dengan inangnya. Selain itu diduga karena ektoparasit tersebut mampu berkembangbiak dengan cepat pada kondisi lingkungan menunjang. Hal ini sesuai dengan pendapat Rustikawati (2004) dalam Panduheriana et al (2019) yang menyatakan bahwa tingginya prevalensi Trichodina sp. dapat disebabkan karena ektoparasit tersebut mampu 
berkembangbiak dengan cepat melalui pembelahan biner.

Pengukuran intensitas serangan ektoparasit ikan putak asal Kabupaten
Musi Banyuasin, Ogan Komering Ilir dan Kota Palembang disajikan pada Tabel 4 berikut ini.

Tabel 4. Nilai Rata-rata Intensitas Serangan Ektoparasit Ikan Putak Asal Kabupaten Musi Banyuasin, Ogan Komering Ilir dan Kota Palembang.

\begin{tabular}{|c|c|c|c|c|c|}
\hline \multirow[t]{2}{*}{ Lokasi } & \multirow{2}{*}{$\begin{array}{c}\text { Berat } \\
\text { Rata- } \\
\text { rata (gr) }\end{array}$} & \multirow{2}{*}{$\begin{array}{c}\text { Panjang } \\
\text { Rata- } \\
\text { rata } \\
(\mathrm{cm})\end{array}$} & \multirow[t]{2}{*}{ Organ } & \multicolumn{2}{|c|}{$\begin{array}{l}\text { Intensitas Serangan } \\
\text { (ind/ekor) }\end{array}$} \\
\hline & & & & $\begin{array}{c}\text { Dactylogyrus } \\
\text { sp }\end{array}$ & $\begin{array}{c}\text { Trichodina } \\
\text { sp }\end{array}$ \\
\hline S1 Penampungan & & & Sirip & - & - \\
\hline Ikan Putak Desa & 34,85 & 16,47 & Insang & 5.61 & 6 \\
\hline Epil Kab. Muba & & & Lendir & 8 & 11 \\
\hline S2 Penampungan & & & Sirip & 16 & 2 \\
\hline Ikan Putak Desa & 36,15 & 16,67 & Insang & 16.14 & 24 \\
\hline Sri Geni Kab OKI & & & Lendir & 4.6 & - \\
\hline S3 Penampungan & & & Sirip & - & - \\
\hline Ikan Putak Sianjur & 35,66 & 16,51 & Insang & - & - \\
\hline 3 Kota Palembang & & & Lendir & - & - \\
\hline
\end{tabular}

Dari Tabel 4 diketahui bahwa nilai intensitas serangan Dactylogyrus sp pada ikan putak di stasiun 1 pada bagian insang sebesar 5,61 ind/ekor dan bagian lendir sebesar 8 ind/ekor, sedangkan intensitas serangan Trichodina sp pada ikan putak pada bagian insang sebesar 6 ind/ekor dan pada bagian sirip sebesar 11 ind/ekor. Untuk stasiun 2 diperoleh nilai intensitas serangan Dactylogyrus sp pada ikan putak bagian sirip sebesar 16 ind/ekor, insang sebesar 16,14 ind/ekor dan bagian lendir sebesar 4,6 ind/ekor, sedangkan intensitas serangan Trichodina sp pada ikan putak pada bagian sirip sebesar 2 ind/ekor dan pada bagian insang sebesar 24 ind/ekor.

Mengacu pada Tabel 4 diatas, diperoleh bahwa bagian sirip, insang dan lendir merupakan bagian ditemukannya ektoparasit, hal ini diduga disebabkan karena Dactylogyrus sp dan Trichodina sp merupakan ektoparasit yang mampu menginfeksi organ sirip, insang dan kulit. Kemampuan Trichodina sp menginfeksi ikan putak dipengaruhi oleh kemampuan melekat yang berkaitan dengan struktur dan morfologi cincin dentikel nya, sedangkan Dactylogyrus sp memiliki alat penghisap bercabang 4 yang berfungsi untuk menempel dan bergerak pada permukaan tubuh inangnya.

Nilai tertinggi intensitas serangan ektoparasit adalah Trichodina sp yang menginfeksi insang ikan putak sebesar 24 ind/ekor pada stasiun 2, disusul oleh Dactylogyrus sp yang menginfeksi insang ikan putak sebesar 16,14 ind/ekor pada stasiun 2 dan Dactylogyrus sp yang menginfeksi sirip ikan putak sebesar 16 ind/ekor pada stasiun 2. Tingginya nilai infeksi ektoparasit yang menginfeksi ikan putak asal stasiun 2 dan disusul dengan stasiun 1, diduga disebabkan 
karena proses transfortasi dari habitat ikan putak yang merupakan hasil tangkapan nelayan setempat ke penampungan ikan di Desa Epil Kabupaten Musi Banyuasin, dan penampungan ikan di Desa Sri Geni Kabupaten OKI dan dilanjutkan dengan transfortasi ke WSPI FPK UPGRIP yang menyebabkan stress pada ikan putak. Menurut Masjudi et al (2016), penyebab stres pada ikan diantaranya disebabkan karena perubahan baik dari eksternal maupun internal. Perubahan eksternal yang menimbulkan respon stres diantaranya adalah perubahan suhu, kekurangan oksigen, dan proses transportasi ikan. Sedangkan pada stasiun 3 Sianjur 3 Kota Palembang tidak ditemukan adanya ektoparasit yang menyerang ikan putak. Tidak ditemukannya ektoparasit ini diduga karena ikan putak yang didapat pada stasiun 3 merupakan ikan putak hasil tangkapan nelayan namun telah dipelihara beberapa waktu sehingga ikan putak tersebut telah mengalami proses adaptasi dengan habitat barunya.

Kriteria penilaian intensitas serangan ektoparasit mengacu pada William dan Bunkley (1996) dalam Maulana et al (2017) yang disajikan pada Tabel 5.

Tabel 5. Kriteria Intensitas Serangan Ektoparasit Menurut William dan Bunkley

(1996) dalam Maulana et al (2017).

\begin{tabular}{ccc}
\hline No & Intensitas (ind/ekor) & Tingkat Infeksi \\
\hline 1 & $<1$ & Sangat Rendah \\
2 & $1-5$ & Rendah \\
3 & $6-50$ & Sedang \\
4 & $51-100$ & Parah \\
5 & $>100$ & Sangat Parah \\
6 & $>1000$ & Super Infeksi \\
\hline
\end{tabular}

Berdasarkan Tabel 5 diatas, intensitas serangan ektoparasit tertinggi pada ikan putak sebesar 24 ind/ekor termasuk dalam kriteria intensitas serangan $6-50$ ind/ekor yang mengindikasikan tingkat infeksi yang sedang. Tingkat infeksi yang sedang pada ikan putak diduga dipengaruhi juga oleh factor ukuran ikan sebagai inang, dimana semakin besar ukuran ikan maka semakin tinggi juga tingkat infeksi dari ektoparasit tertentu. Sedangkan nilai intensitas serangan ektoparasit terendah sebesar 2 ind/ekor termasuk dalam kriteria intensitas serangan $1-5$ ind/ekor yang mengindikasikan tingkat infeksi yang rendah.

\section{KESIMPULAN}

Kesimpulan dari hasil penelitian ini adalah jenis ektoparasit pada ikan putak asal Kabupaten Musi Banyuasin, Ogan Komering Ilir dan Kota Palembang yang ditemukan adalah Dactylogyrus sp dan Trichodina sp, Indeks prevalensi dan intensitas tingkat serangan ektoparasit pada ikan putak asal Kabupaten Musi Banyuasin, Ogan Komering Ilir dan Palembang berada pada kategori tingkat infeksi yang rendah hingga sedang.

\section{DAFTAR PUSTAKA}

Agustinus, F., Gusliany. 2020. Kandungan Isi Usus Ikan Putak (Notopterus notopterus) Hasil 
Tangkapan Nelayan di Perairan Lubuk Lampam Kabupaten Ogan Komering Ilir Sumatera Selatan. Bulletin Teknik Litkayasa Sumber Daya dan Penangkapan. Vol.14 (1) : 19-21

Bayumi., Yusanti, I.A., Anwar, S., Mulyani, R. 2021. Identifikasi Ektoparasit Ikan Patin Siam (Pangasius Hypopthalmus) Pada Kelompok Pembudidaya Ikan Di Sungai Ogan Kabupaten Ogan Ilir. Jurnal Sainmatika. Vol.18 (1) : 68-75

Kabata, Z. 1985. Parasites and Diseases of Fish Cultured in The Tropics. Tailor and Feancis Inc. London and Philadelphia. 318 hal.

Masjudi, H., Tang, U. M., dan Syawal, H. 2016. Kajian Tingkat Stres Ikan Tapah (Wallago Leeri) Yang Dipelihara Dengan Pemberian Pakan Dan Suhu Yang Berbeda. Berkala Perikanan Terubuk. Vol.44(3) : 69-83

Maulana, D. M., Muchlisin, Z. A., dan Sugito, S. 2017. Intensitas dan Prevalensi Parasit Pada Ikan Betok (Anabastestudineus) dari Perairan Umum Daratan Aceh Bagian Utara. Jurnal Ilmiah Mahasiswa Kelautan dan Perikanan. 2(1) : 1-11.

Panduheriana, U. M., dan Abdillah, A. A. 2019. Studi Kejadian Ektoparasit Pada Pembesaran Ikan Bawal Bintang (Trachinotus blochii) Di Balai Layanan Usaha Produksi Perikanan Budidaya (BLUPPB) Karawang, Jawa Barat. Jurnal Akuakultur Rawa Indonesia. Vol.7(1) : $46-54$.

Utami, P., dan Rokhmani, R. 2016. Spesifisitas Parasit Protozoa Trichodina Sp. Pada Gurame, Tawes, Nilem Dan Nila Yang Dibudidayakan Polikultur.
Seminar Nasional Pendidikan dan Saintek. ISSN : 2557-533X : 86-91

Wibowo, A., Sunarno, M.T.D., Subagja., Hidayah, T. 2009. Karakterisasi Populasi Ikan Putak (Notopterus Notopterus) menggunakan Analisis Keragaman Fenotipik dan Daerah 16 SRNA DNA Mitokondria. Jurnal Penelitian Perikanan Indonesia. Vol.15 (1) : 1-12.

Yuli, S., Harris, H., Yusanti, I. A. 2017. Tingkat Serangan Ektoparasit Pada Ikan Patin (Pangasius Hypopthalmus) Yang Dibudidayakan Dalam Keramba Jaring Apung Di Sungai Musi Palembang. Jurnal Ilmu-ilmu Perikanan dan Budidaya Perairan. Vol.12 (2) : 50-58.

Yusuf, M., Yusanti, I.A., dan Sofian, S. 2020. Tingkat Serangan Ektoparasit Pada Ikan Lele (Clarias sp) Yang Di Pelihara Pada Media Budidaya Yang Berbeda. Skripsi. Program Studi Ilmu Perikanan Fakultas Perikanan dan Kelautan Universitas PGRI Palembang. Xvi +59 hlm. 